九州大学学術情報リポジトリ

Kyushu University Institutional Repository

\title{
The Pork Consumption and Distribution in Urban Areas of Vietnam before WTO Accession
}

Nguyen, Thuy Minh

Graduate School of Bioresource and Bioenvironmental Sciences, Kyushu University

Yutaka, Tomoyuki

Faculty of Agriculture, Kyushu University

Fukuda, Susumu

Faculty of Agriculture, Kyushu University

Kai, Satoshi

Faculty of Agriculture, Kyushu University

https://doi.org/10.5109/9270

出版情報：九州大学大学院農学研究院紀要. 51 (2)，pp.459-466，2006-10-27. Faculty of Agriculture, Kyushu University

バージョン :

権利関係 : 


\title{
The Pork Consumption and Distribution in Urban Areas of Vietnam before WTO Accession
}

\author{
NGUYEN Thuy Minh', Tomoyuki YUTAKA, Susumu FUKUDA \\ and Satoshi KAI*
}

Laboratory of Food Marketing, Division of Industrial Organization of Agribusiness, Department of Agricultural and Resource Economics, Faculty of Agriculture, Kyushu University,

Fukuoka 812-8581, Japan

(Received June 29, 2006 and accepted July 24, 2006)

\begin{abstract}
Pork is the most popular type of meat in the daily meals of Vietnamese people. Pig industry provides jobs to a great number of Vietnamese farmers who in most of the cases run a very small-scaled operation. This paper investigates the current situation of the pig and pork consumption and distribution in Vietnam before the entry to WTO which is estimated by October 2006. The writers also try to make some estimation about the changes in the pig production and distribution after the accession. It is required that the pig and pork distribution system is modernized and improved immediately to face with the challenges brought about by the accession.
\end{abstract}

\section{INTRODUCTION}

After nearly 11 years of negotiations, on May 31, 2006 the US and Vietnam signed an agreement on the terms and conditions for Vietnam's accession to the World Trade Organization (WTO). This is the essential step that helps Vietnam to obtain the consensus with the remaining WTO members on the final entry. It is estimated that Vietnam will become a member of WTO by October, 2006.

The accession to WTO would bring about not only opportunities but also challenges to Vietnam's mar- ket-oriented economy which is fledgling though being in fast growth. Especially, the accession would have great effects on the agriculture which employs around 70\% of the country's population. This paper aims at identifying how the entry to WTO may influence the consumption and distribution of pork in the urban areas of Vietnam.

\section{IMPACTS OF THE ACCESSION ON THE PORK CONSUMPTION}

\section{A promising retail market}

The income per capita of Vietnamese people has

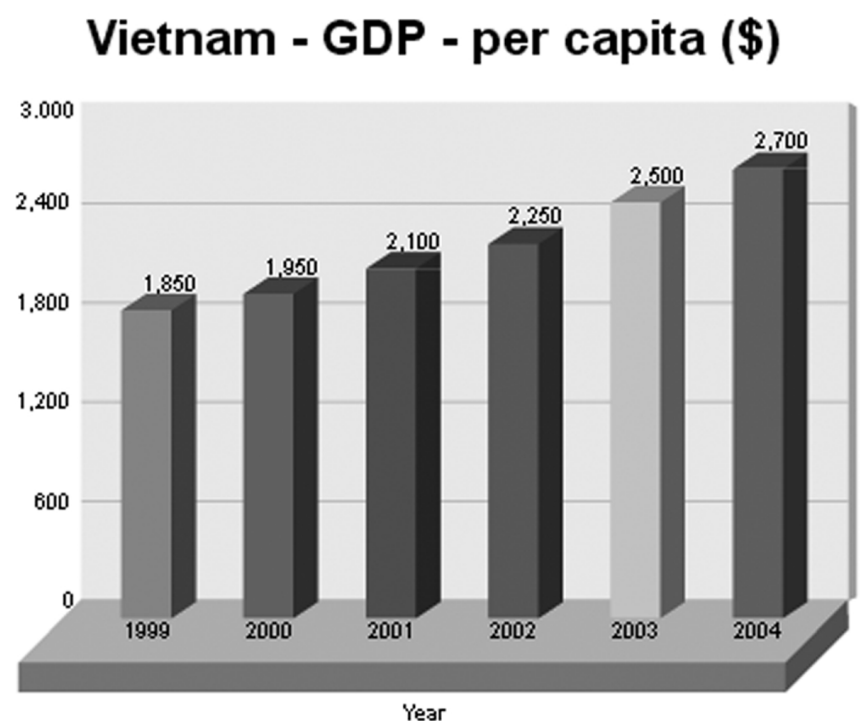

Fig. 1. Vietnam's GDP per capita in term of Purchase Power Parity. Source: http://www.indexmundi.com

\footnotetext{
1 Laboratory of Food Marketing, Division of Industrial Organization of Agribusiness, Department of Agricultural and Resource Economics, Graduate School of Bioresource and Bioenvironmental Sciences, Kyushu University, Fukuoka 812-8581, Japan

* Corresponding author (E-mail: satokai@agr.kyushu-u.ac.jp)
}

Table 1. Vietnam's GDP growth rate

\begin{tabular}{lccccccc}
\hline Year & 2001 & 2002 & 2003 & 2004 & 2005 & $\begin{array}{c}2006 \\
\text { (est.) }\end{array}$ & $\begin{array}{c}2007 \\
\text { (est.) }\end{array}$ \\
\hline $\begin{array}{l}\text { GDP } \\
\begin{array}{l}\% \text { change } \\
\text { previous year) }\end{array}\end{array}$ & 6.9 & 7.1 & 7.3 & 7.7 & 8.4 & 8.0 & 7.5 \\
\hline
\end{tabular}

Source: World bank 


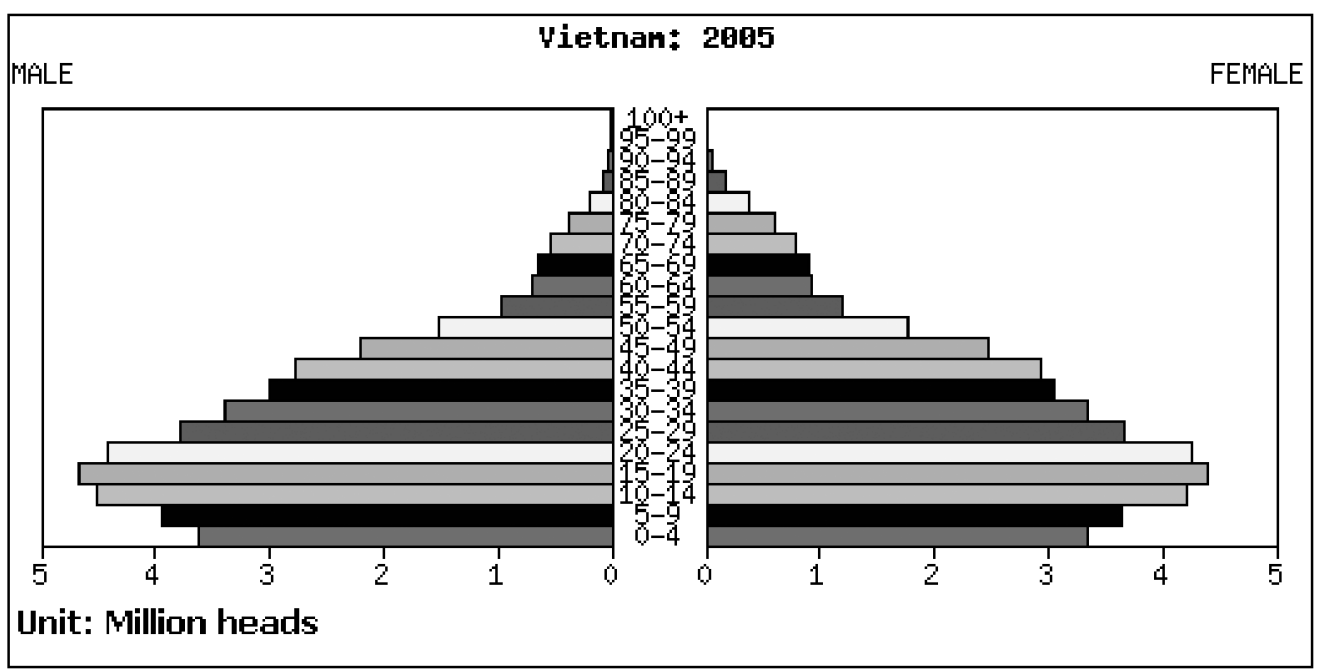

Fig. 2. Population pyramid.

Source: U.S. Census Bureau, International Data Base

\begin{tabular}{|c|c|c|c|c|c|c|c|c|}
\hline \multirow{2}{*}{$\begin{array}{l}2006 \\
\text { rank }\end{array}$} & \multirow[b]{2}{*}{ Country } & \multicolumn{2}{|c|}{ Region } & $\begin{array}{l}\text { Country } \\
\text { risk }\end{array}$ & $\begin{array}{c}\text { Market } \\
\text { attractiveness }\end{array}$ & $\begin{array}{c}\text { Market } \\
\text { saturation }\end{array}$ & $\begin{array}{c}\text { Time } \\
\text { pressure }\end{array}$ & \multirow{2}{*}{$\begin{array}{l}\text { GRDI } \\
\text { score }\end{array}$} \\
\hline & & \multicolumn{2}{|c|}{ Weight } & $25 \%$ & $25 \%$ & $30 \%$ & $20 \%$ & \\
\hline 1 & India & \multicolumn{2}{|l|}{ Asia } & 55 & 34 & 89 & 76 & 100 \\
\hline 2 & Russia & \multicolumn{2}{|c|}{ Eastern Europe } & 43 & 59 & 53 & 90 & 85 \\
\hline 3 & Vietnam & \multicolumn{2}{|l|}{ Asia } & 43 & 24 & 87 & 81 & 84 \\
\hline 4 & Ukraine & \multicolumn{2}{|c|}{ Eastern Europe } & 42 & 37 & 76 & 81 & 83 \\
\hline 5 & China & \multicolumn{2}{|l|}{ Asia } & 58 & 40 & 57 & 86 & 82 \\
\hline 6 & Chile & \multicolumn{2}{|c|}{ Americas } & 67 & 57 & 47 & 48 & 71 \\
\hline 7 & Latvia & \multicolumn{2}{|c|}{ Eastern Europe } & 58 & 50 & 31 & 88 & 69 \\
\hline 8 & Slovenis & \multicolumn{2}{|c|}{ Eastern Europe } & 78 & 52 & 25 & 70 & 68 \\
\hline 9 & Croatia & \multicolumn{2}{|c|}{ Eastern Europe } & 57 & 51 & 28 & 91 & 67 \\
\hline 10 & Turkey & \multicolumn{2}{|c|}{ Mediterranean } & 46 & 59 & 64 & 40 & 66 \\
\hline ঐ & $\begin{array}{l}\text { On the radsr screen } \\
\text { To consider }\end{array}$ & $\begin{array}{l}\text { Lower } \\
\text { prioriny }\end{array}$ & 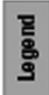 & $\begin{aligned} 0 & =\underset{h i g h}{\text { hish }} \\
100 & =\operatorname{low}_{\text {risk }}\end{aligned}$ & 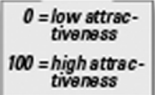 & $\begin{aligned} 0 & =\text { satursted } \\
100 & =\text { not } \\
& \text { sstursted }\end{aligned}$ & $\begin{aligned} & 0=\text { no oime } \\
& \text { pressure } \\
& 100= \text { urgency } \\
& \text { to enter }\end{aligned}$ & \\
\hline
\end{tabular}

Fig. 3. The 2006 Global Retail Development Index ${ }^{\mathrm{TM}}$.

Source: Euro money, World bank, Global competitive report 2005 and A. T. Kearney analysis

been increasing continuously in the past decade.

Fast economic growth, especially in foreign investment and exports sectors has driven the GDP per capita (on PPP basis) in 2004 by one and a half of that at the end of 1990s. And this is estimated to increase at around the same rate in the coming years.

In the Global Retail Development Index published in 2006 by A.T. Kearney, a U.S. leading strategic management consulting firm, Vietnam ranks the third as the most attractive retail market. About one-fourth of the population are in the 10-20 year age group and more than half are under 25 years old.

Consumer spending increased by about $16 \%$ and modern retail sales rose by 20\% from 2004 to 2005 . Some giant retailers namely Metro Cash\&Carry, Bourbon have come to establish their business in Vietnam and many others are setting their plan to penetrate into this emerging market.

\section{Consumption of pork}

Pork is the most commonly consumed type of meat and accounts for around $73 \%$ of consumption of meat in 2003.

Consumption of pork has been increasing over the

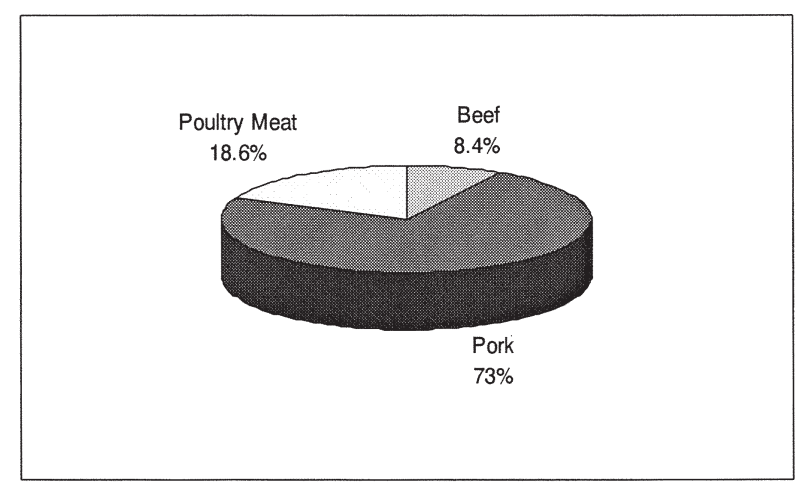

Fig. 4. Meat consumption proportion-2003. 
Table 2. Pork supply and demand of Vietnam

\begin{tabular}{lllllllllll}
\hline Year & 1995 & 1996 & 1997 & 1998 & 1999 & 2000 & 2001 & 2002 & 2003 & 2004 \\
\hline Pork production (tmt) & 1007 & 1052 & 1154.2 & 1228 & 1318.4 & 1409.02 & 1515.3 & 1653.6 & 1795.4 & 2012 \\
Exports (tmt) & 6.4 & 4.626 & 64.799 & 66.667 & 69.486 & 74.236 & 50.088 & 14.452 & 9.660 & 17.314 \\
Imports (tmt) & 0.119 & 0.15 & 0.125 & 0.1 & 0.025 & 0.019 & 0.019 & 0.032 & 0 & 0 \\
Domestic supply (tmt) & 1000.719 & 1047.524 & 1089.526 & 1161.433 & 1248.939 & 1334.803 & 1465.231 & 1639.115 & 1785.7 & 1994.7 \\
Growth rate & & $4.677 \%$ & $4.010 \%$ & $6.600 \%$ & $7.534 \%$ & $6.875 \%$ & $9.771 \%$ & $11.867 \%$ & $8.9 \%$ & $11.7 \%$ \\
Annual qty per person & \multirow{2}{*}{13.7} & 14.2 & 14.5 & 15.3 & 16.2 & 17.1 & 18.5 & 20.4 & 22 \\
\hline
\end{tabular}

Source: FAO

Table 3. How do the following criteria affect your decision to purchase pork?

(Unit: \%)

\begin{tabular}{lcccccc}
\hline Criteria & 5 & 4 & 3 & 2 & 1 & $\begin{array}{c}\text { No } \\
\text { grade }\end{array}$ \\
\hline $\begin{array}{l}\text { Freshness } \\
\text { Convenient place }\end{array}$ & 22.72 & 63.63 & 9.09 & & & 4.54 \\
\hline
\end{tabular}

Source: Survey 2005

years and not yet saturated when compared with that of other countries, for example, an average Chinese consumed $35.3 \mathrm{~kg}$ of pork in 2003 where as an average Vietnamese only consumed $22 \mathrm{~kg}$. The consumption of pork will definitely increase dramatically in the years to come.

Vietnamese traditionally consume fresh pork sold at the traditional wet markets. Chilled pork has been introduced to the market recently but accounts for a very insignificant percentage of the market. The two most important factors that consumers would consider when they buy pork are Freshness and Convenience. A survey done in 2005 in Hanoi reveal the following results:

Freshness is seen as the most important factor in the decision of pork purchase. The freshness of the pork has a great influence on the taste of the food made from it as the fresher the meat the better the taste. Freshness is also seen as a measure to avoid the risk that may be brought about by unsanitary food. According to CIRAD/IOS investigation carried out in 2002, 96.5\% of Hanoi consumers would buy fresh food to protect themselves from risky effects from food.

Convenience One important factor that consumers do concern is the market location. Everyone would choose to buy things, especially daily goods, somewhere near their houses. Besides, the conveniently located markets that could be found easily in the street corners enable the consumers to do shopping within several steps from their home. The modern retailing system, i.e. supermarkets, has not well developed and does not offer wide selection of fresh food like vegetables and fruits, moreover, difficulties in parking facilities, etc are the main reasons why consumers still choose traditional markets as the place for their daily shopping.

After becoming a member of WTO, Vietnam is expected to gain more economic achievements. The changes would have influence the pork consumption in the following ways:

-Higher income allows consumers to spend more on food and pork. Though it is hard to estimate how high the income would increase after Vietnam's joining to WTO, more investments and job opportunities, more access to foreign markets are easily foreseen and these would drive up the living standards as well as the optimism of the consumers which will encourage them to spend more. The income elasticity of demand for pork is estimated at 0.642 for the period from 1995-2004.

$\log ($ Pork supply $)=3.33+0.642 \log (G D P)$

$$
\text { (11.558) (13.445) } \quad R^{2}=0.957
$$

That means, if the income (GDP) increases by $10 \%$, the demand for pork would increase by $6.42 \%$. The income elasticity of demand for pork for the period 1990-2000 was 0.28 only. The increased elasticity indices agree with the change in the nutrition structure. In the first years of economic growth, any surplus in income was spent on staple food like rice. After the demand for staple food is saturated, the consumption for rich-in-protein and more expensive food increases.

-Changes in the lifestyle will be the result of economic development as has been seen in the case of more developed countries. Higher income also allows consumers to go to supermarkets more frequently and they may turn away from the traditional markets. The consumption of pork through the modern retailing system will therefore be promoted.

The consumers with better living standards will concern more about the safety of their food. If they are made to fully understand about the risks of the ordinary fresh pork at the traditional markets and the merits of the pork in the modern retailing system, their buying habits would be changed accordingly. Besides, industrialized lifestyle would put more time pressure and the opportunity cost for shopping time will be higher. Consumers will tend to save their time by doing shopping less frequently but with larger quantity for each time. Chilled food would become more popular and replace fresh food in the daily meals of the Vietnamese consumers.

\section{Impacts of the accession on the meat imports}

As per the WTO accession agreement with the U.S. signed on 2006, the import tariff on meat will be cut down. As this agreement would constitute the overall commitments of Vietnam to WTO, all the agreements on tax reduction would be applied at the same rates or even lower to the meat imports from other WTO member countries too.

Before this agreement, the tariffs levied on pork 
Table 4. Tariffs on pork in reduction schedule

\begin{tabular}{lccccc}
\hline & $\begin{array}{c}\text { Before } \\
\text { WAA }\end{array}$ & $\begin{array}{c}\text { WAA } \\
2006\end{array}$ & $\begin{array}{c}\text { WAA } \\
2010\end{array}$ & $\begin{array}{c}\text { WAA } \\
2011\end{array}$ & $\begin{array}{c}\text { CEPT } \\
2006\end{array}$ \\
\hline $\begin{array}{c}\text { Pork offals } \\
\begin{array}{c}\text { Pork fresh, } \\
\text { chilled, frozen }\end{array}\end{array}$ & $20 \%$ & $15 \%$ & $8 \%$ & $8 \%$ & $5 \%$ \\
$\begin{array}{c}\text { Processed pork } \\
\text { products }\end{array}$ & $20 \%$ & $20 \%$ & $20 \%$ & $10 \%$ & $5 \%$ \\
\hline
\end{tabular}

Source: http://www.customs.gov.vn; Fact sheet on bilateral market access agreement on agricultural goods.

WAA: U.S. -Vietnam WTO Bilateral Market Access Agreement

imports were set high at $30-45 \%$ and lower for the imports from the ASEAN countries under the CEPT (commonly effective preferential tariffs) agreements.

One important point to note is that as per the WTO access agreement with the U.S., tariffs on pork offal are agreed to be reduced immediately to $15 \%$ and to $8 \%$ after 4 years from now. U.S. exporters seem to have an interest in Vietnam as a market for their offal products. In the U.S., consumers usually do not eat the offal so the prices are much lower in terms of the ratio to the prices of other pork products. By contrast, in Vietnam, offal products are very popular in the daily meals and the prices are high in comparison to other parts of the carcass. For example, the ratio of pork tongue price to loin price in the U.S. is $41 \%$ only whereas it is around $108 \%$ in Vietnam. It is estimated that the first U.S. pork products to enter Vietnam's market would be the offal. Note that pork offal products accounted for around 80\% of pork imports from the U.S. to China in 1999.

The main pork producers in the region are not yet the threat to the local pig industry. The pig industry of China and Thailand is still in subsistence level and the surplus is not enough to be a significant source for exports. Besides, both China and Thailand's pig industries are suffering from Foot and Mouth disease and pig products (with the exception of some heat processed products) from these countries are prohibited to enter Vietnam's market. The U.S., Canada, Australia, New Zealand, which are low cost and disease-free pork producers, would be the potential competitors to local farmers.

Thanks to the mass production, the cost for one $\mathrm{kg}$ of carcass weight is about $\$ 1.17$ in the U.S., $\$ 1.58$ in Denmark. Meanwhile, the production cost in the traditional pig farming system and in the commercial farming system in Vietnam is $\$ 0.48$ and $\$ 1.03$ respectively (Minh's survey 2005) or $\$ 0.68$ and $\$ 1.47$ respectively for one $\mathrm{kg}$ of carcass weight. Vietnamese pork, especially that of the commercial system, is not competitive against the U.S. produce. The only obstacles against the penetration of overseas pork to Vietnam's market are transportation cost and tariffs.

Tariffs on beef offal would also be reduced from the current MFN level of 20\% to $15 \%$ immediately and $8 \%$ after 4 years. Boneless beef tariff will be cut from $20 \%$ to $14 \%$ after 5 years. The U.S. bilateral agreement does not mention poultry products but the tariffs have been
Table 5. Retail prices of pork in several markets on April 26, 2006 Unit: VND/kg

\begin{tabular}{lccc}
\hline \multicolumn{1}{c}{ Items } & $\begin{array}{c}\text { Metro } \\
\text { (wholesaling) }\end{array}$ & $\begin{array}{c}\text { Traditional } \\
\text { market } \\
\text { (retailing) }\end{array}$ & $\begin{array}{c}\text { Wholesale } \\
\text { price } \\
\text { in the U.S. }{ }^{1}\end{array}$ \\
\hline Rump & 29,500 & 32,000 & \\
Rump lean & 37,500 & 38,000 & \\
Belly & 24,900 & 30,000 & 24,880 \\
Debonned leg & 28,500 & 30,000 & 18,270 \\
Ribs & 37,900 & 40,000 & \\
Bones & 15,800 & 20,000 & 32,440 \\
Loin & 46,900 & 45,000 & \\
Shoulder lean & 34,500 & 38,000 & \\
Shoulder & 27,500 & NA & \\
Minced pork & 32,900 & NA & \\
Pork tounge & & 50,000 & \\
\hline
\end{tabular}

Source: Minh's survey 2006; http://www.100my.net

${ }^{1}$ : Wholesale price of pork in March 2006; Exchange rate: 1USD $=16,000 \mathrm{VND}$;

removed for the imports from ASEAN countries under CEPT. It is estimated that beef and poultry products from low-production cost countries would enter the local meat market of which beef still accounts for a very small share due to the underdevelopment of the commercial beef cattle and poultry industries. This may lead to changes in the structure of the meat consumption in Vietnam.

\section{THE PIG PRODUCTION AND DISTRIBUTION BEFORE THE WTO ACCESSION}

If the commercial farming is not promoted right now, the local market would be supplied mostly by the small-scaled farmers who are raising about $70 \%$ of the national pig herd. Small-scaled farming has the advantage of low cost and therefore the pork is competitive against imports. Besides, small-scaled production benefits poor farmers who might be redundant and low-income labor. However, small-scaled production is an obstacle against the long-term development of the industry because it presents danger to the health of the livestock and the consumers due to the poor control over sanitation conditions. If any fatal disease ever occurs, like the case of birdfluenza, huge losses to the farmers and the market might be caused and even become unable to control. If the local pork is prohibited then, the whole market will be lost to the foreign suppliers. On the other hand, small-scaled farming would fail to supply pork of the uniform quality classification to the modern distribution system and prevent the development of the distribution system.

The commercial farming system should therefore be positively promoted right now. This could be achieved by promoting the modern retail system. If the market for the high quality pork is secured, the production costs would be lowered and keep the pork price competitive even after the tariffs barriers against pork imports are reduced or removed. 
Joining into WTO does not bring about greater opportunities to Vietnam's pork exporters, at least in the short time. The production cost is too high in comparison with the world's main pork exporters. For example, the live pig price in Hochiminh city in 2004 was $1,116 \mathrm{USD} / \mathrm{MT}$, much higher than the pork price in Russia and the U.S. which was 1,070 USD/MT and 868USD/MT respectively (Source: Vn Economy).

Besides, Vietnam pig industry has been suffering from Foot and Mouth disease which limits the access of Vietnam's pig and pork to another country. At the moment, Vietnam is exporting suckling pigs to Hongkong and Taiwan at very small quantities.

Before Vietnamese pig producers could gain more access to foreign markets, a lot still should be done to improve the competitiveness of their products.

\section{Impacts of the accession on the pig production}

Animal feeds account for $70 \%$ of the total production cost in pig commercial farms in Vietnam (Minh's survey 2005). Annually Vietnam has to import a lot of ingredients for the feed industry, including soybean meal from India, Argentina (934,000 Mts) in 2004, (Source: Quangdung Co. Ltd), corn from China (700,000 Mts), fishmeal from Peru, Malaysia (30,000 Mts), etc. Local production has become dependent on the supplies from these countries, and also on the oil price that constitutes the sea transportation costs. In order to lessen the burden for the feeds industry, imports tax levied on feed ingredients has been lowered from 2001. Oil extracted meal categories which account for the largest percentage in the production formula, have been enjoyed tax level of $0 \%$.

It is estimated that further reduction might be made to the import tax rates but there will not be significant change in the production cost of feeds because the tax rates have already been lowered.

By the end of 2004, there were 260 feed mills all over the country more than a half of that were small-sized factories with capacity of less than 30Mts per month. Small-sized feed mills target to the smaller commercial farms and even subsistence farmers whereas almost all larger feed processors instead have established their own distribution system with local sales agents. Their customers are mainly large commercial farms who have

Table 6. Imports tax and VAT tax on feeds ingredients (up to August 2005)

\begin{tabular}{lrr}
\hline \multicolumn{1}{l}{ Ingredients } & $\begin{array}{c}\text { Imports } \\
\text { tax }\end{array}$ & VAT \\
\hline $\begin{array}{l}\text { Soybeanmeal, Rapeseedmeal, Groundnut meal, } \\
\text { Rice bran, Lactose* }\end{array}$ & $0 \%$ & $5 \%$ \\
$\begin{array}{l}\text { Wheatbran pellets, Corn, Wheat, } \\
\text { Malaysian fishmeal }\end{array}$ & $5 \%$ & $5 \%$ \\
$\begin{array}{l}\text { Wheat gluten, Corn gluten meal, Meat\&bone } \\
\text { meal, Peruvian fishmeal, Squid liver oil, Blood } \\
\text { meal }\end{array}$ & $10 \%$ & $5 \%$ \\
$\begin{array}{l}\text { Whey powder } \\
\text { Lysine }\end{array}$ & $20 \%$ & $10 \%$ \\
Fishoil & $15 \%$ & $10 \%$ \\
& $10 \%$ & $10 \%$ \\
\hline
\end{tabular}

high requirements for the quality of feed products. Most of the largest feed producers like CP from Thailand, Cargill from the U.S., Proconco from France have established their business in Vietnam, there are almost no imported final feeds in the local market. At the moment, the imports tax of final feed products is 10\%, 15\% and $5 \%$ for those under preferential tax system, common tax system and CEPT respectively.

Until now, Vietnam has almost no long-term strategies to increase the self-sufficiency ratio of feed ingredients. This puts a constraint to the livestock industry and keeps the pork production costs high and uncompetitive against the pork products from overseas. The Feed Conversion Rate in Vietnam was 3.0-3.2 in 2003 which means it needs $3.0-3.2 \mathrm{~kg}$ feed to produce $1 \mathrm{~kg}$ live pig, as $1 \mathrm{~kg}$ live pig could bring $0.70 \mathrm{~kg}$ carcass, then it needs $4.28-4.55 \mathrm{~kg}$ feed to produce $1 \mathrm{~kg}$ carcass. As the imports tax is reduced or removed, it would become more economic to import pork carcasses than to import feed ingredients to produce those carcasses domestically.

As per the commitments to WTO members, government support to pig and pork industry would be stopped after 3 years since the accession. At the moment, supports from the government to pig and pork industry is limited to the money rewarded to pork exporters who earn VND900 per one U.S. dollar of exports. As Vietnam's pork has lost its exports market, total financial incentives to pig industry have been reduced to nearly zero.

\section{The pig and pork distribution system in the} preparation for the accession

Current distribution channel of pig and pork

-Channel for pigs slaughtered in traditional slaughterhouses

Pigs might be marketed directly by farmer households or commercial farms, but in most of the cases, they are gathered by traders or smaller collectors then resold to the slaughterhouses. The slaughterers then supply the carcasses to the retailers in the traditional wet markets throughout the city.

-Channel for pigs slaughtered in industrially equipped slaughterhouses

This channel represents a very insignificant share of the market.

-Channel for pigs slaughtered outside the urban cities' slaughterhouses

This channel is bringing one of the biggest concerns about the food sanitary as it is very difficult to keep control over the currents of slaughtered pigs from peri-urban areas or far provinces to urban market. In this channel, pigs are slaughtered right at the farmer households then transported in small quantities, usually from 1 to 2 carcasses mainly by motorbikes to the city. This pork is sold mainly in the spontaneous selling points outside the organized markets.

The structure of the distribution channel differs from one city to another. In the North, slaughterers tend to work independently from each other, their 


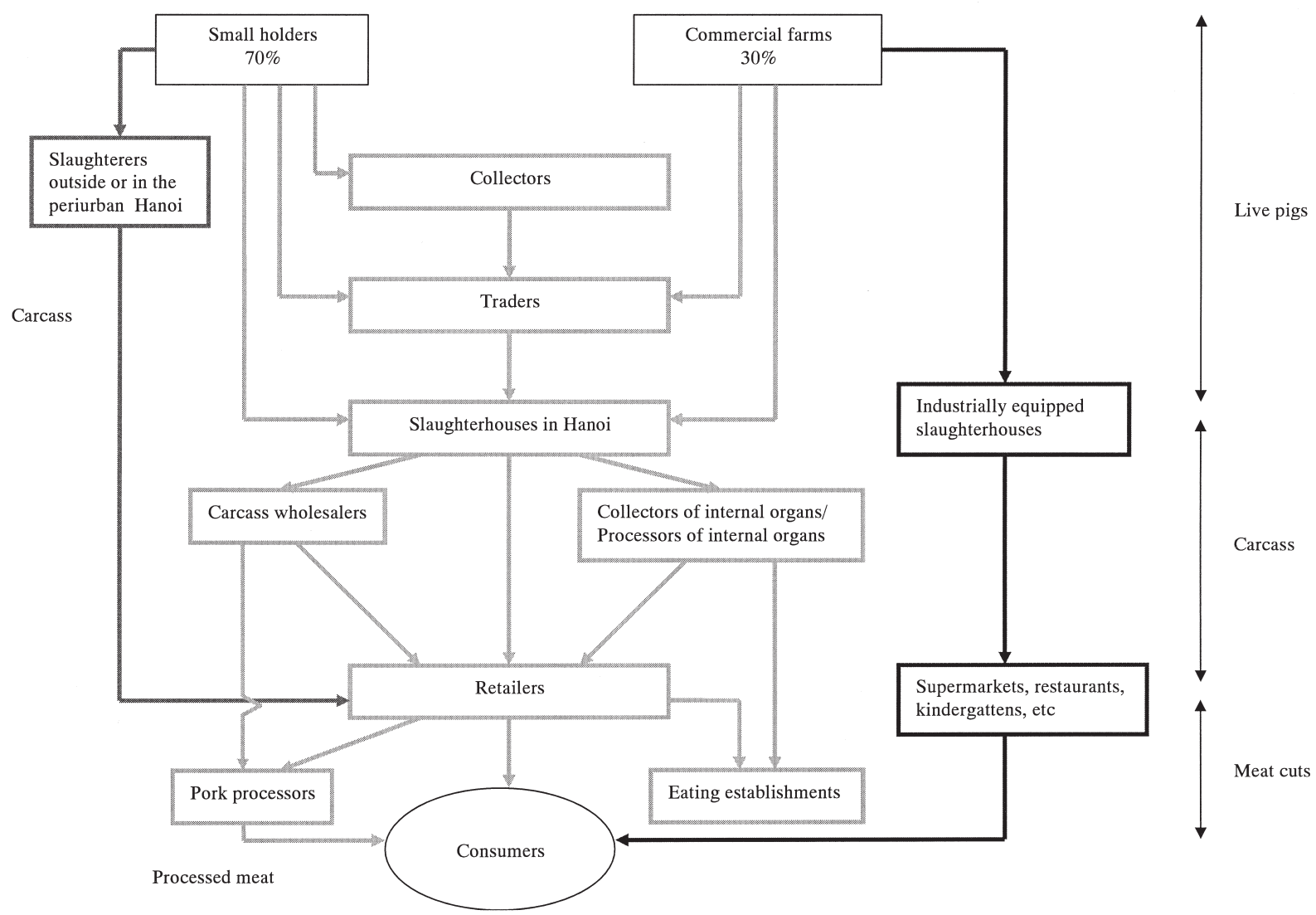

Fig. 5. Slaughter pig marketing channels in Hanoi (North of Vietnam).

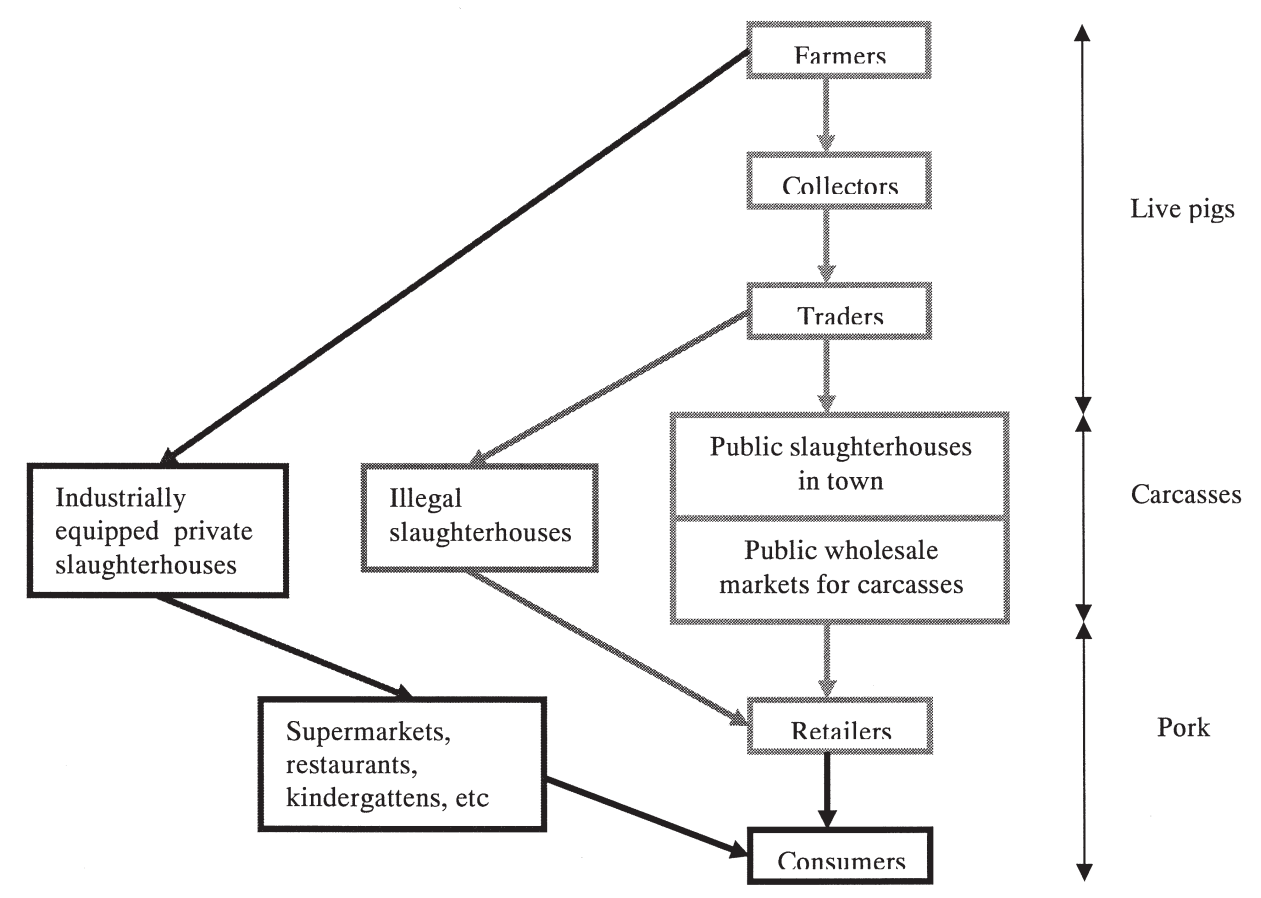

Fig. 6. Slaughter pig marketing channels the South Source: Katell le Gouven and others. 
operation scale is therefore small. The slaughterhouses are privately owned and run. The slaughterers in the North set up and maintain their own network of pig providers and pork retailer-customers. The slaughterers lead the power over the other two agents as they normally provide loans to traders and sell to retailers on credit. The relationship among traders, slaughterers and retailers are individual-based. Meanwhile, in the South, slaughtering activities are conducted mainly at State-owned slaughterhouses. The carcasses are sold to retailers at auction sales and credit is provided through a funding system outside the pork distribution channel. The buying and selling relationship among agents is therefore independent and not influenced by any of them. Vietnam's accession to WTO will therefore have different impacts on the slaughtering activities of the North and the South.

As the consumers become more demanding for the quality and safety of the pork and the retailing system develops to meet this changing demand, it is easier and faster for the slaughterhouses in the South to adapt by applying more advanced technologies and equipments. By contrast, it will take long time for individually-run slaughterhouses in the North to invest in their premises to improve the quality and safety of pork. The high-end demand could therefore only be satisfied by the industrially equipped slaughterhouses run by meat processors which still account for a very insignificant percentage of the supply at the moment.

\section{PORK RETAILING BEFORE WTO ACCESSION}

Almost pork in Vietnam is sold at the traditional wet markets. Each retailer sells one to two carcasses per day. Food safety control is done by inspection staff at the selling stalls. The inspection is based on the appearance of the pork only. Besides the organized markets, there are unorganized markets which have been increasing in number. The unorganized markets do not have fixed premises and are poor in safety conditions. The retailers in the unorganized markets might come from rural areas. The pigs that are slaughtered outside the cities are mainly sold at these markets. Meanwhile, the law enforcement is not strong enough to eliminate the existence of the markets.

The first supermarkets came to exist in Vietnam since the beginning of 1990 s and they are growing fast both in terms of number and of operation scale. However, the fresh food sold at the supermarkets still accounts for a very insignificant percentage in sales turnover. Pork sold at the supermarkets is supplied from some meat processors who specialize in exporting to Hongkong or Taiwan markets. This pork is sold at much higher price than in the traditional wet markets and only targets high-end customers. In order to appeal the ordinary consumers, some meat processors (Ducviet Co., as an example) have set up sales corners right in the traditional markets. However, the advertisements are not effective and influential enough as they still fail to convince the consumers about the differentiation between their pork and the pork sold at the traditional markets.

After Vietnam joining WTO, more world's leading retailers would become interested in exploring the local market. The modern retailing system is estimated to develop fast in the years to come. In order to appeal the consumers from the traditional markets, these retailers would have to extend their sales lists to serve more fresh food, including pork. Metro, a wholesaler who has come to Vietnam since 2003, has been successful to sell pork at lower price than the traditional markets. The constraint is that Metro could only sell at large-volume packages. But this proves that means pork could be sold at supermarkets at appealing price as long as the consumption is large.

The foreign retailers have the advantages of large investments and much better experience. At one hand, they are a great danger to the local retailers who are small-sized and less professional in operation. But on the other hand, they would accelerate the modernization of the local retailing system and provide consumers with better access to higher quality and better safety food. The modern retailers would secure their supplies by contract systems with farmers. Only those farmers who could provide safe and quality-uniform produce at low price could be selected and maintain in the distribution system. Small-scaled and subsistence farmers might face danger of being expelled from the market of the urban areas. Also, traders and collectors might also disappear as retailers would choose to set up direct relationship with producers.

\section{SUMMARY AND CONCLUSION}

Vietnam's accession to WTO would bring about both opportunities and threats to the pig industry and pork market of Vietnam. The demand for pork is estimated to increase due to the improved income and industrialized lifestyle of the urban citizens. The retailing system is forecast to be modernized at a faster speed.

On the other hand, joining WTO does not bring about a larger exports market for pork as it may to other agricultural products. It is because the pig production cost in Vietnam is very high and makes the pork uncompetitive. Besides, animal health is still a big problem in Vietnam. By contrast, the imports tax levied on pork will be lowered and local producers have to face competition from foreign suppliers if they fail to adapt to the changes before imported pork could enter the local market at more affordable price.

In order to improve the competitiveness of the pig industry, the followings are recommended:

1. To accelerate the modern retailing system. Encourage the supermarkets and other modern retail outlets to include Safe pork in their sales list. During the first 3 years after the accession, support to pig industry which is not yet required to be eliminated should be focused on the introduction of Safe pork through the modern retailing system, firstly in the main urban areas. The expansion of the modern retailing 
system would have affect on the production in the way that the pig farmers have to improve the quality and safety of their products, industrialize the production so that the pigs are of the uniform quality at the same time keep the price competitive. This favors the large-scaled farmers and also gives an alert to the small-scale farmer communities and makes them more aware of the threats after the market protection measures are completely removed as the commitments to WTO.

2. Efforts should be focused to increase the self-sufficiency ratio of feed ingredients. It is necessary to minimize the feed cost and hence production cost, otherwise the local market would be endangered by the pork from those countries that are self-sufficient of the feeds and could keep their costs at a very competitive level.

3. The regulations on animal health and food safety must be strongly enforced. The illegal slaughterhouses that do not meet the safety standards must be closed down. Also, the transportation of carcasses slaughtered outside the city must be forbidden. This would help to encourage the modern retailing system and narrow down the wet market system which contains risks of spreading contagious diseases and does harm to consumers' health.

4. Last but not least, pig producers should improve their own performance by looking more into technical matters and marketing activities.

\section{REFERENCES}

G. R. Griffith 2004 The impacts of supermarkets on farm suppliers The Australian Economic Review, 37(3): 329-36

Katell le Goulven 2001 Institutions and Price transmission in the Vietnamese hog market International Food and Agribusiness Management Review, 2(3/4): 375-390

Leo Den Hartog 2004 Developments in Global pig production, http://www. banffpork.ca

William Ampohsah, Xiang Dong Qin, Xuehua Peng 2001 China as a potential market for U.S. pork exports Review of Agriculture Economics, 25(1): 259-269 